\title{
Health care at a premium
}

The Ontario government's reintroduction of health care premiums has proved the most controversial feature of its recent budget. Any new tax generates controversy - and a premium is a tax in all but name. This premium has proven especially controversial both because it broke an explicit election promise and because it touched a deep vein of ambivalence. Ontarians, like all Canadians, value public health care, but they have been told that lower taxes are an economic imperative. The premium is caught in the endless debate about the sustainability of, and reform to, our health care system.

The Ontario health care premium applies to individuals, is indexed to income and creates no new eligibility criteria for receipt of publicly funded health care. The premium rises from zero for those whose taxable income is less than $\$ 20000$ to $\$ 900$ for those whose income is $\infty$ over \$200 000. Overall, it will raise $\$ 2.4$ billion in revenue, about $8 \%$ of annual public health care spending in Ontario. ô The only other provinces that $\stackrel{0}{\circ}$ use premiums as a financing mechanism are British Colum$\curvearrowleft$ bia and Alberta, where they are

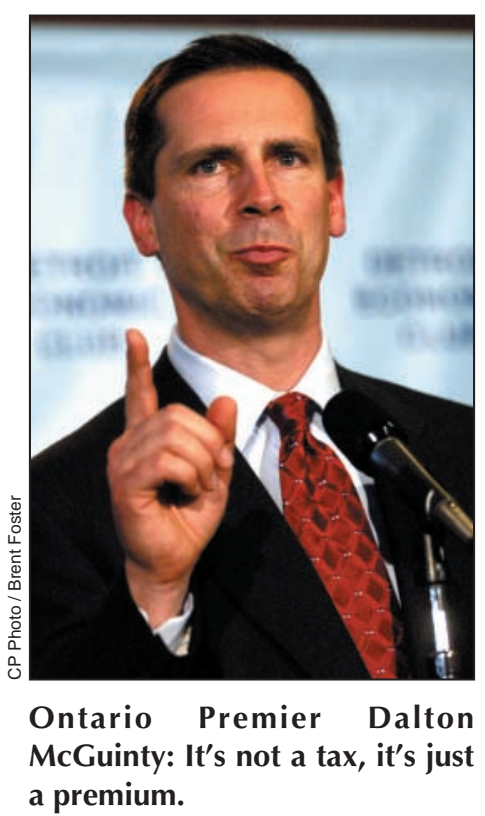

levied on households rather than on individuals and vary according to household structure (e.g., single, family). They are constant over most of the income range, however, with subsidies provided only to those with a low income. Both provinces raised their premiums in 2002, Alberta by $29 \%$ and British Columbia by $50 \%$.

Although the Ontario premium increases in absolute terms as income grows, the proportion of income it represents falls as income rises; it is therefore a regressive tax. Income indexing makes it less regressive than British Columbia's and $\mathrm{Al}$ berta's premiums, as well as Ontario's previous fixed health care premium, which was abolished in 1989 in view of the burden it imposed on the poor. But the structure of the new premium perpetuates the regressive redistribution of wealth in Canada over the last decade. The large personal and corporate tax cuts of the last decade have disproportionately benefitted wealthy Canadians, ${ }^{1}$ while new public revenues have invariably been raised from regressive sources outside the progressive income tax system: user fees, property taxes, "sin" taxes (liquor, cigarettes, gambling) and health care premiums. Canadian governments are systematically substituting regressive taxes for progressive taxes. Health care premiums need not be regressive, but in the Canadian experience they are. Perhaps this is because a progressive system of premiums is a hard sell given the well-known inverse correlation between income and health care need. A "premium," after all, suggests a closer correspondence between payment and risk status than does a tax.

The Ontario government felt compelled by its dire fiscal situation to reintroduce health care premiums. The government could not, given the deficit it had inherited, honour its elec- tion promises to invest simultaneously in education and health care, balance the budget and hold the line on taxes. The government judged the best course of action (politically and otherwise) to be to invest in health and education while raising new revenue via the premium. The Canadian public, after all, has indicated a willingness to pay higher taxes dedicated to health care. Although the premium revenue has been explicitly linked to health care, the strategy must be seen in part as a move to create fiscal room to invest in education and to protect spending on programs other than health, many of which were fiscally starved under Harris's Common Sense revolution.

Is the premium a sign of the much-claimed unsustainability of medicare? Here we must distinguish between economic sustainability and budgetary sustainability. Economic sustainability refers to our ability to maintain current and anticipated levels of health spending given the size of our overall economy. Canada's health care system is, from a purely economic perspective, eminently sustainable. Canada spends between $9 \%$ and $10 \%$ of its national income on health care, ${ }^{2}$ well within the range of other nations. Spending on medicare has constituted a surprisingly stable share of national income for 3 decades. ${ }^{1}$ Moreover, health spending on medicare services has risen more slowly than spending in those components of the system with mixed public-private financing or predominately private financing. ${ }^{2}$ The international evidence is incontrovertible: single-payer publicly financed health care is far more economically sustainable than is a multi-payer system with substantial private finance.

Budgetary sustainability, which is at risk, refers to the ability of those organizations charged with paying the bills to do so with the budget available 
to them. Since the federal and provincial governments underwent a painful - and necessary - fiscal retrenchment in the early 1990s to restore their fiscal probity, they have spent a large portion of their fiscal dividend on tax cuts rather than on program spending. The combined public revenues forgone by cuts to federal and provincial personal and corporate income taxes between 1996/97 and $2003 / 04$ is estimated to be $\$ 170$ billion; in 2003/04 alone the public sector revenue forgone is estimated to be $\$ 49.9$ billion, more than $60 \%$ of current public expenditure on health care. ${ }^{1}$ As a society, we have systematically constrained the income of the key organizations - the federal and provincial governments - most responsible for financing health care. The result, not surprisingly, has been to make it impossible to sustain publicly financed health care without making cuts into non-health program spending. But there nothing immutable, no iron law of economics, behind this phenomenon: it is the result of po- litical choices. Given economic sustainability, budgetary sustainability is fundamentally a political, not an economic matter. These fiscal choices may reflect the trade-offs that Canadians want to make - they did elect the governments after all though polling data suggest that matters are a bit more clouded. In this respect, it is worth noting that, although it promised not to increase taxes, the Ontario Liberal government was elected campaigning against Conservative promises of more tax cuts.

Canadians can have publicly financed health care if they want it. Economic history shows that societies can publicly finance social and health programs without sacrificing economic performance. ${ }^{3}$ What we can't simultaneously have is public health care, tax cuts and balanced budgets.

Finally, although the health care premium has been promoted as an essential part of health system reform, it likely will not play an instrumental role in that reform. It may buy more services (depending on fee and wage settlements), but there is little evidence that the billions of additional public dollars pumped into health care since 1997/98 has bought any meaningful change. More reform was probably accomplished in the mid-1990s, during the short period of fiscal retrenchment, than in any time in recent history. In fact, the new money will make it easier to avoid the hard changes our system requires. Real reform needs political will and strategies to challenge the status quo.

\section{Jeremiah Hurley}

Centre for Health Economics and

Policy Analysis

Department of Economics

McMaster University

Hamilton, Ont.

\section{References}

1. Evans RG. Political wolves and economic sheep: the sustainability of public bealth insurance in Canada. Vancouver: University of British Columbia Centre for Health Services and Policy Research Working Paper; 2003:03-16W.

2. Canadian Institute of Health Information. National bealth expenditure trends: 1975-2003. Ottawa: The Institute; 2003.

3. Lindert P. Growing public: social spending and economic growth since the eighteenth century. Cambridge (UK): Cambridge University Press; 2003.

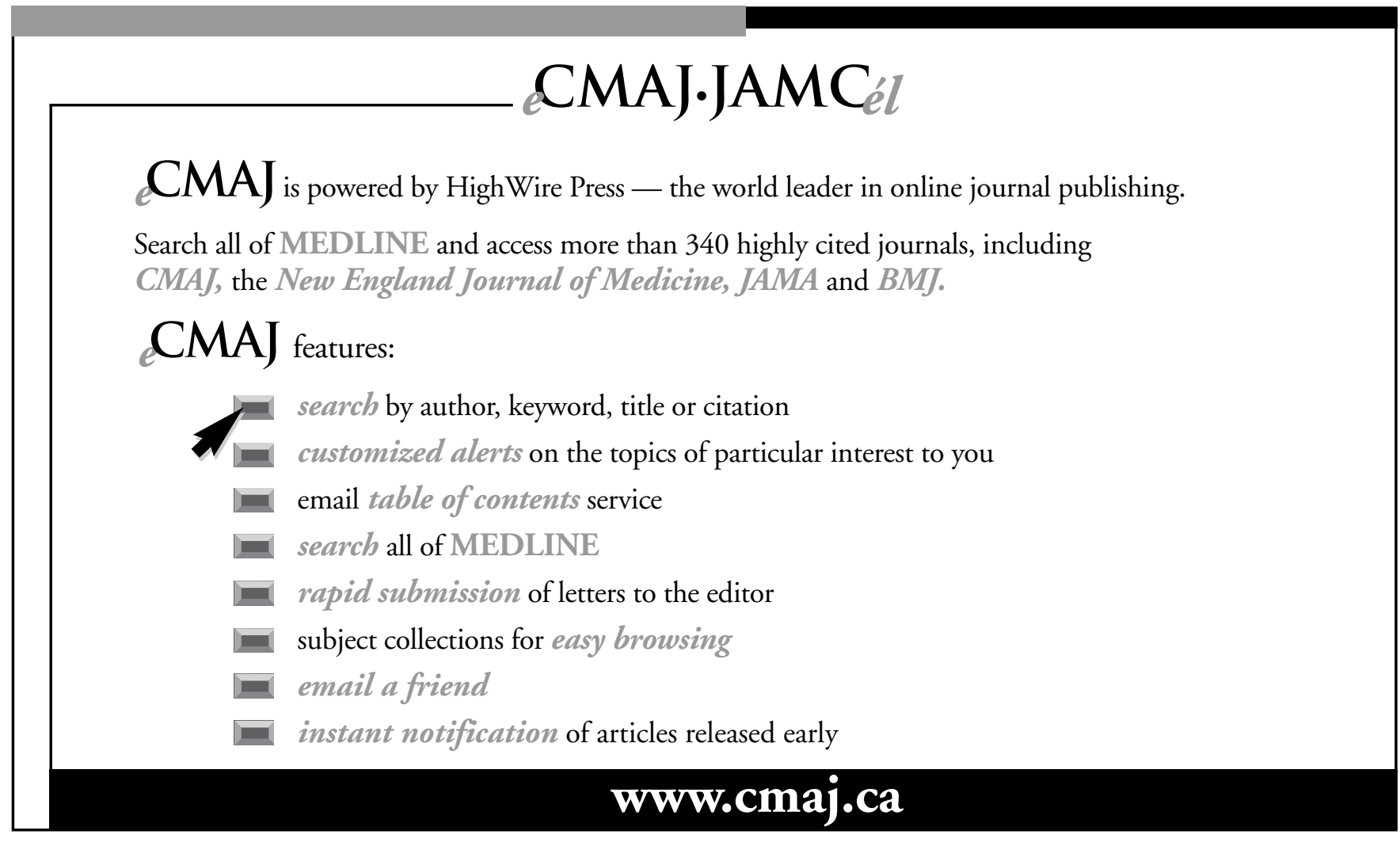

